\title{
İslam Coğrafyasında Erken Dönem Medrese Bileşenleri Üzerine
}

\author{
Seda DEMIR ${ }^{1}$ \\ Öz
}

Bilindiği üzere, medreseler, özellikle İslamiyet'in ilk yıllarından itibaren ortaya çıkmış, İslami ilimlerin ve kendi döneminin akademik çalışmalarının orta ve yüksek düzeyde gerçekleştirildiği eğitim kurumlarıydı. Müslümanların fethettikleri şehirler ile yeni kurdukları yerleşim merkezleri, yüzyıllar boyunca devam eden ekonomik ve sosyal değişim, kozmopolit şehir toplumlarının ve büyük imparatorlukların şekillenişi, yalnızca siyasi olaylara yön vermekle kalmadı aynı zamanda İslam medeniyetinin yükselişinin de temellerini oluşturdu. Osmanlı İmparatorluğu'na kadar devam eden ve ylllar içinde çeşitlenerek her ait olduğu Müslüman kültüre adapte edilen; çeşitli mezheplerden ekol olarak etkilenmiş ve kendini genişletmiş olan bu kurum türü 16. asır ortalarında çöküş sürecine girmiştir. Nasıl ve hangi sosyo-politik koşullarda ortaya çıkıp teşkilatlandıkları, nasıl yönetildikleri, öğretim sistemlerine yönelik detaylar ve toplumda bir eğitim kurumu olarak nasıl yer edindikleri noktasında özellikle önemli detayların ele alındığ1 bu çalışma medreselerin ilk dönemlerinden itibaren sosyal ve akademik bileşenlerin onu karakteristik bir eğitim kurumu haline getiren ögelerini inceleyip detaylandırmayı hedeflemektedir.

Anabtar Kelimeler: Erken dönem medrese, İslam’da Yükseköğretim, Medrese Teşkilat1, Medrese Eğitimi, İcazet, Medrese Tarihi

\section{Over early Madrasas of Medieval Islamic Geography and Its Components}

\begin{abstract}
As known, madrasas were educational institutions that emerged especially from the very first years of Islam, and they were the educational institutions where Islamic science and academic studies of their period were carried out at medium and higher study levels. The cities conquered by Muslims, the newly established settlements, the economic and social change which continued for centuries, the formation of cosmopolitan urban societies and great empires not only shaped political events but also formed the basis of the rise of Islamic civilization. Survived until the Ottoman Empire, diversified over the centuries and adapted to each Muslim culture, this type of institution, which was influenced by various sects and expanded itself, entered a period of collapse in the mid-16th century. The study, which deals with important details in terms of how and under which socio-political conditions they emerged and organized, how they were managed, how they took place as an educational institution in the society and details of education systems has been traced from the first periods of madrasas.
\end{abstract}

Key Words: Early Madrasa, Islamic Higher Education, Organization of Madrasa, Higher Education in Madrasa, Idjazat, History of Madrasa

\section{Atıf İçin / Please Cite As:}

Demir, S. (2021). İslam Coğrafyasında Erken Dönem Medrese Bileşenleri Üzerine. Manas Sosyal Araștırmalar Dergisi, 10(3), 1678-1691.

Geliş Tarihi / Received Date: 14.11.2020

Kabul Tarihi / Accepted Date: 09.04.2021

\footnotetext{
${ }^{1}$ Doktora Öğrencisi - Sakarya Üniversitesi Eğitim Bilimleri Enstitüsü, serkoc_16@hotmail.com

iD ORCID: 0000-0002-3044-8530.
} 


\section{Giriş}

Fetihlerle teşekkül eden yeni merkezler ile ortaya çıkan topluluklar, İslamiyet'in yeni formlarını ve İslam kültürünü ortaya koymuştur. Bunların en önde gelenlerinden biri medrese olacaktır. Dirâse, tercümesi ile "okumak, anlamak, bir metne çalșmak ve ezberlemek için tekrarlamak" kökünden ortaya çıkmış bir mekân ismi olan medrese günümüze kadar ulaşan haliyle İslami eğitim merkezlerinden ilk akla gelenlerin temel türüdür. Üniversitelerin yükselişinden çok daha önce var olmuş olan bu kurumlar İslam dünyasına ait ve tamamen İslami normların içinden doğmuşken; Orta Çağ üniversitesi Batı'ya, özellikle de Avrupa'ya özgü bir kurumdur. Antik dünyada ya da İslam dünyasında temel olarak aynı yapı taşlarına dayandırılabilecek okullar var olmuş olsa da yalnızca yükseköğretim sağlayan kurumlar olması dışında tam olarak benzer, emsal oluşumlar olduklarını söylemek yanlış olabilir. Kaldı ki Orta Çağ üniversitesi daha çok aynı konuları çalışmak üzere bir araya gelmiş öğrenci topluluklarının kurdukları birlik ve lonca özellikleri teşkil eden yapıların zamanla eğitimcilerin de oluşturdukları ile birlikte kurumlaşmaya başlayan hallerinden ortaya çıkmıştır. Oysa medresenin kökenini İslamiyet'le birlikte şekillenen öğretilerin zamanla cami ve ulema evlerinin dışına taşan öğretimlerin kurumlaşma sonucu belirdiğini söylemek yanlış olmaz.

Selçuklular ve Fâtımîler gibi çağdaşlarına ait eğitim kurumlarının yapı taşlarına ilişkin sistematik bilgi ve bu bilginin dönemin sosyal ve siyasi özellikleri bağlamında ele alındığında ortaya çıkacak panoramayı yabancı literatür destekli zenginleştirmek çalışanın temel problemini oluşturmaktadır. Aynı bağlamlar üzerine yazılmış mevcut çok sayıda çalışmanın aksine çalışma, yabancı kaynaklı araştırmalardan da oldukça geniş oranda istifade etmiş, daha çok İslam dünyası ve medreselerin Türk-İslam dünyasına girişi ile Türk araştırmacılara mal olmuş medrese konu başlığını uluslararası literatürdeki araştırmacıların tespitleri ile destekleme noktasında bir boşluğu doldurmayı hedeflemektedir.

\section{Medreselerin Ortaya Çıkışında Camiler}

Bilim merkezi olarak medreselerin yaygınlaşması, ücretsiz eğitim sağlamaya başlamaları ve farklı Müslüman coğrafyalara yayılması özellikle Selçuklular zamanında İslamiyet'e oldukça büyük oranda hizmet etmiştir. Yine Selçuklular döneminden önce İran, Horasan ve Türkistan gibi yerlerde hali hazırda kurulmuş olan diğer dini nitelikli eğitim merkezlerinin- ribat, zaviye gibi kurumların- evvelki katkıları ise azımsanmayacak kadar fazladır. "İslami eğitim Hz. Muhammed zamanında başlamasına rağmen eğitim kurumlarının teşekkülü (İslamiyet'in) ikinci yüzyllını bekleyecektir” (Campo 2009, s. 446). Böyle olmakla beraber cami veya mescitlerin medreselerin bir prototipi, öncülü veya ilk halleri olduğu düşünülebilir. Çünkü bu kurumlar halkın dini ibadetlerini yapıp dini konular hakkında fikir alışverişinde bulunduğu, İslam hukukunu, şeriatı öğrendiği yerlerdi. "Meclis" ise Müslümanların toplanıp belirli bir konu hakkında mantık yürüttüğü sohbet halkalarıydı. Bu terim içinde tartışma (münazara meclisi), bilimsel akıl yürütme (ilm meclisi) eylemini de barındırıyordu. Medresenin asıl kökenini, özünü mescidlerin ve camilerin içinde kurulan meclisler oluşturuyordu. Bir başka deyişle medrese, hamiliği veya yöneticiliğini yapan kişiye bağlı olarak herhangi bir İslam ilminin çalışıldığı bir başka dini kurum olan mescitten ortaya çıkmıştır. Mescitler, İslamiyet'le birlikte ortaya çıkmış, medreseler çok daha sonra kurulmuştur. Medreselerin kuruluşundan önce ilim meclislerinde mescitlerde, halkalarda, maristanlarda ve bimaristanlarda, tup merkezlerinde, hastane veya kütüphaneler de ilmi konular tartışıllp, çalışıllyordu. O dönemde başta ders veren hocaların evinde olmak üzere, zaviye, hangah gibi özel mekânlarda düzenli olarak ilim meclislerinin tertip edildiği, önemli hadis kitaplarının okunduğu ve müzakere edildiği bilinmektedir (Yllmaz, 2013). Medreselerin doğuşu ile birlikte yabancı ilimlerin çalışılması yavaş yavaş azalmış ve ismi içinde "dâr" kelimesi taşıyan yeni kurumlar ortaya çıkmaya başlamıştır. Bunlar içtihat ilmi veya Kur'an eğitimlerinin yayılmasını sağlayan kurumlar olup aralarında Darü'l-Kur'an, Darü'l-Hadis, Beytü'l-Hikme gibi kurumlar da var olmuştur ve bu kurumlar medrese öncesi teşekkül etmişlerdir (Baltac1, 1973, s. 5; Ergün, 2015, s. 31-31). 10. Asırda dikkati çeken başat bir eğitim kurumu olarak medrese ilk önce Karahanlılar zamanında ortaya çıkmış ve bu isimle anılmaya başlamıştır (Baltac1, 1973, s. 5). Medreseler cami-han kombinasyonundan türemişlerdi (Arjman, Mirsafa ve Talebi, 2017) çünkü her ikisi de aynı ortamda eğitim ve konaklama imkânlarına sahip kurumlardı. Ayrıca bu kurumlar, var olan bilginin sistematikleştirilmesinin yanı sıra dini ve hukuki ilimlerde bilgilenmeyi de sağlıyordu.

\section{Dönem Toplumunun Sosyolojik Alt Yapısı, Şia ve Bu Ekole Göre Kurulan Okullar}

Hıristiyan ekümenik dünyada bile kader ve özgür irade, cehennem, sonsuz ceza hakkında anlaşmazlık söz konusuydu. Aynı konular, teolojik İslam halkalarında da tartışlıyordu. İşte bu tartışmalar bahsi geçen entelektüel akımların ortaya çıkmasına sebep olan şeylerdi. Tüm bu akımlar aynı şekilde düşünen ve inanan 


\section{DEMIR}

insanların yollarının kesişmesine, bazı konuları öğretmek ve öğrenmek için düzenli olarak bir araya gelmelerine neden oldu ve bu da medrese sisteminin ortaya çıkmasını sağladı (Al-Hassan 2001, s. 76). Bu türden tartışmalar, camilerde İslami ilimlerin öğretilip tartışıldığı halkalarda ve meclis adı verilen sosyal oluşumlarda ortaya çıkmıştı.

Fatimi (909-1171) halifesi El-Hâkim 988'de Kahire'de bugünkü Ezher Üniversitesinin temeli olan ElEzher Medresesini kurdurdu. Bu medresede başta Fizik ve Matematik olmak üzere birçok bilim alanında öğretim yapıllyordu. Kitap sayısı milyonları aşan büyük bir kütüphanesi vardı. Fatimiler döneminde Kahire Bağdat'1 gölgeleyecek kadar büyük bir kültür ve ticaret merkezi olmuştu (Günay, 1999). Şiiler arasında, dini ve yasal ögrretim Sünni Müslümanlar arasında da uygulandığı gibi, yalnızca camide sağlanıyordu. El-Ezher Kahire'deki en prestijli üniversitelerden (camia) biriydi ve 972 y1linda, 969'da Misır'1 fetheden Fatimi ordusunun komutanı (Sicilyalı) Cüvher Kâtip tarafindan bir Şii öğrenim merkezi olarak kurulmuştu. Üniversitenin Şii öğretileri yalnızca isminde değil Şî̀ şeriatinin temeli olan müfredatına da yansıtılmıştır. Üniversite aynı zamanda coğrafya ve tarihte olduğu kadar doğa bilimleri, tıp, matematik, astronomi dersleri veren bir seküler öğretim kalesi niteliği taşıyordu (Cosman vd. 2009, s. 148).

10. asırda, Büveyhiler denilen bir Şii hanedanlığı, artık sembolik bir Sünni Abbasi halifesine sahip Abbasi Irak ve İran üzerinde hâkimiyet sağlamıştır. Büveyhiler, 11. asırda Orta Asya'da Türkçe konuşan bir millet olan Sünni Selçuklular tarafından yenilene kadar kontrolü ellerinde tutmuşlardır. 969 yilında Kuzey Afrika'dan Fatimiler, Kahire ve Mısır üzerinde güç kazanmış buralardaki Sünni nüfusu 1171 yılında Eyyübiler tarafindan yenilene dek yönetimde olmuşlardır. İşte, Fatimilerden geriye kalan entelektüel miraslardan biri de 972 yllında kurulan ve Fâtimî Şiası doktrini ve öğrenimini yaymaya çalışan -az önce sözü edilen- Mısır'daki El-Ezher Camii ve Medrese Kompleksi'dir. Fatimilerin düşüşünün hemen ardından takip eden iki yüzyıl boyunca oldukça güçlü bir Sünni çabası Şii etkisini azaltmaya çalışıştır. Medrese çoğu açıdan bu dini kampanya ve entelektüel gerilemeyle savaşan klasik bir öge haline gelmiştir. Bu durum El-Ezher üniversitesinin, bugünkü haliyle olduğu gibi 12. asrin en önemli Sünni yükseköğrenim merkezi haline dönüşmesine büyük ölçüde yansımıştır (Afsaruddin, 2005).

Irak, Suriye ve Mısır'da Büveyhoğulları (334-447/945-1055) ve Fâtımîler'in (297-556/910-1171) yaptıkları Şî' lik propagandalarına karşı Selçuklular, askeri yönden Sünniliği savunmakla kalmadılar, fikri kuruluşlarla görüşlerini takviye de ettiler. Şiiliğe yönelik bir "karşı propaganda" olarak medreseler kuruldu ve bu medreselere devlet desteği de sağlandı (Gül, 1997, s. 5).

1067 yllında Bağdad'da Nizamiye Medreselerinin açılışı medrese sisteminin başlangıç noktasına işaret etmektedir. Daha sonra çok sayıda Nizamiye açılmıştı; diğer bölgelerde bu medreseler ve medrese sistemlerinden açmanın mantığı, İslam hukuku ve İslam teolojisine yönelik görüş birliği oluşturmaktır (Campo, 2009). Gerçi Alparslan'dan önce Gazneli Mahmud Gazne'de, kardeşi Emir Nasr Nişabur'da medrese benzeri eğitim kurumları tesis etmişlerdi; ancak bunlar medreseler kadar sistemli değildi (Sarıçam, vd., 2018, s. 178). Bağdat'ta 6. /12. asırda Nizamiye medreseleri düşüşe geçtiğinde, entelektüel anlamda en önemli okullar Hanbeli olanlardı. Ancak Nizâmü’l-Mülk’ün aşırı mezhep partizanlığına karşı kanıt olarak gösterilebilecek şey, Bağdatlı Hanbeliler halka Eşarilik eğitimi verilmesini protesto ettiklerinde yaptığı ve Hanbeli İbnül-Cevzi tarafından şiddetle nakledilen çarpıcı açıklamasıdır: "Sultanın politikası ve adaletin gerektirdikleri herhangi bir mezhebe yönelip diğerlerini dışlamamamızı gerektirmektedir; biz, mezhep çatışmasından yana olmaktan ziyade geleneksel inancı ve uygulamalarını güçlendirmeyi istiyoruz. Bu medreseyi (Nizamiye) de yalnızca akademisyenleri gözetmek ve halkın menfaatine olması için inşa ettik; anlaşmazlık ve fitne için değil” (Fisher vd., 1968, s. 73) Nizâmü'l-Mülk, Nizamiyelere uygun akademisyenlerin atanması işini kişisel bir sorumluluk olarak görmüştü. 459/1067 yılında medreseyi açtı̆̆ında akademisyen Ebu İshak eş-Şirazi ve daha sonrasında 484/1091 yllında kendisi henüz Horasan dışında çok az tanınıyordu ve 33 yaşında iken teolog ve filozof Ebu Hamid el-Gazalinin burada ders vermelerini sağlamak adına çok büyük emek verdi. 479-80/ 1081 yllında Kuzey Suriye seferini bitirdikten sonra Melikşah'ın Bağdat'a ilk ziyaretinde, Nizâmü'l-Mülk'ün bizzat hadis ve sünnet üzerine Nizamiye'de ders verdiği bilinmektedir (Fisher vd., 1968, s. 72).

Dârü'l-İlm ve Dârü’l-Hikme gibi özel kurumlar Şii dünyasında 10. asırdan itibaren ortaya çıkmaya başladı. Bu kurumlar, Şii İslami bilimlerinin ve (tıp, astronomi, matematik gibi) seküler bilimlerin her branşında eğitimin sunulduğu okuma odaları ve sınıfları olan geniş kütüphanelerdi. Dârü'l-Hikme tüm dünyadan gelecek akademisyenlere açıktı fakat müfredatı ve yönetimi Şii öğretilerini yansıtıyordu; yani aynı zamanda haftalık seminerler de veren baş Şii Dâ̂̀'d-duât tarafindan yönetiliyordu (Cosman vd., 2009, s. 148). Şii mezheblerinden olan İsmâiliyye ve Karmatîlerde İsmâiliyye ve Karmatîler'de "da'vet" adı verilen 
mezhep faaliyetlerini yürütmek için imam tarafindan yetki verilmek suretiyle tayin edilen dâiler, mezhep bünyesi içinde önemli bir mevkiye sahiptirler ve bu en yüksek dâî, her türlü ilim ve mezhep faaliyetlerini yürütme konusunda bir üst rütbe olan hüccete karşı sorumluydu (Öz, 1993, s. 420-421).

"Bazı bölgelerde iki soydaş kurum yani medrese yalnızca dini konularda eğitim vererek ve Dârü'lilimler, özellikle Yunan geleneğinin rasyonel bilimlerini öğreterek yan yana var olmuştur” (Ellwood 2012: 118). Yani bu dönemde medreselerin yanı sıra yükseköğrenim hizmeti sağlayan başka kurumlar veya oluşumlar da var olmuştur. Ellwood'un yazdıklarından medreselerin daha önceleri rasyonel bilimler alanında eğitim vermediği, İslami eğitim sağladığı çıkanımında bulunulabilir. "Sünni türlerin azalmasına karşılık bazı Şii akademisyenler öğretilerini ana akıma daha uygun hale getirmişlerdir. İki ekol arasındaki çatışmalar Müslümanlar Haçlı seferlerine karşı koymak için birleştiğinde giderek azalmış ve gerilemiştir" (Rosenwein, 2014, s. 158).

Nizâmü'l-Mülk gibi Mezapotamya'da hüküm sürdüğü süre zarfında Orta Çağ’da Suriye ve Mısır'daki eğitime katkı sağlayan hükümdarlar yaşamıştır ve bu hükümdarlar, Nureddin ve Selahattin, üstlendikleri görevler ve eğitime sağladıkları katkılar açısından Nizâmü'l-Mülk'e mevkidaş ve muadil olarak düşünülebilir. "Nizâmü'l-Mülk, Fatimi Şii misyonerlerinin dava isimli hareketinin hızla artan ilerleyişine karş1 çıkmak için Sünni İslam kalesi yaratmak istemiştir. Nizamiye medreselerinde okuyan öğrenciler, Kur'an, Hadis ve Arap filolojisine ek olarak dört Sünni İslam hukuku hakkında eğitim almışlardır. Bu kurum türü Nasrid Hanedanlı̆̆ altında Hindistan'dan Granada'ya kadar çok sayıda başka ülkeye de yayılmıştır "(Cosman vd., 2009, s. 69). Bu kurumlar kısa sürede İslam dünyasının hemen her tarafina yayıldı. Sultanlar, vezirler, beyler ve hatta hatunlar dahi medrese açma konusunda birbiriyle yarışa girmişlerdir. Halife Muntasır, 631/1233 yllında dört mezhep için muhteşem bir eğitim yeri olan Muntasırriyye medresesini kurmuştur (Sarıçam vd. 2018, s. 178). Böylece daha önce mezhebe dayalı öğretim amacıyla açllmış bulunan Daru'l-Hadis ve Daru'l- Hikme medreselerinin tek yanlı eğitiminden farklı olarak temel dini doğruların özgür bilimsel ortamda tartışılıp öğretilmesinin ve halka gerçek dini aktarmanın yolu açılmıştır (Cebeci, 2004, s. 197). Medrese eğitimi Osmanlı döneminde ikincil evresini yaşamıştır fakat Osmanlılardan önceki dönemlerde; başka bir deyişle Orta Çağ Arap dünyasında İslamiyet’in hâkim olduğu diyarlarda üç çeşit medrese kurumu mevcuttu. Genel eğitim ve öğretime tahsis edilen medreseler yanında, belli branşlarda eğitim faaliyetlerini sürdüren ihtisas medreseleri de vardır ki bunlar da Dâru'l-Hadis, Dâru'l-Kurra ve Dâru't-T1b gibi isimlerdir (Kazıc1, 2010, s. 29).

Daru'l-hadis: Hz. Muhammed'in cümle ve söylemlerinin çalışıldığı kurumlardı. "Yer, mekân, ev" gibi anlamlara gelen dâr ile hadîs kelimesinden oluşan dârü'l-hadîs "hadis okutulan yer" demektir. Bu müesseselere "dârü’s-sünne", "dârü’s-sünneti'n-nebeviyye" veya "dârü’s-sünneti'l-Muhammediyye" adı da verilmiştir (Bozkurt, 1993, s. 553). Darü'l-hadis, terim olarak "hadis evi' veya 'hadis yurdu ancak hadis ilimlerinin her çeşidinin ihtisas derecesinde öğretildiği kurum demektir (Gözütok, 2012, s. 244). Müfredatını yoğunlukla hadis öğrenimine tahsis eden bu kurumlar, İslâm coğrafyasında Daru'l-hadis adıyla ilk defa hicri altıncı asırdan itibaren Dımaşk'ta ortaya çıkmaya başlamıştır. Bu yapıların ilk örneği ise Dımaşk ve Halep Atabegi Nûreddîn ez-Zengî̀ye (ö.569/1174) nispet edilen ve meşhur tarihçi İbn Asâkir (ö.571/1175) adına yaptırllan Nûriye Dârülhadisi'dir (Kalaç, 2020, s. 67).

Dâru't-tip: hekimlik ve tıbbi bilgi nakledilen kurumlar.

Dâru'-kurra: Kur'an-1 Kerim'in yedi farklı üslupla nasıl okunacağını öğreten kurumlardır (Creswell, 1920, s. 35).

\section{Dönemin Önemli Yükseköğretim Merkezleri}

Arap fetihlerinin ardından Mezopotamya'da Doğu ve Batı arasındaki sınırların kalkmaya başlamasıyla yeni bir kültürel atmosfer ortaya çıkmıştı. Sınırların kaldırılması bir taraftan Büyük İskender'den beri bin yıldır Helenleştirilmeye tabi tutulmuş insanları ve bölgeleri birleştirirken, diğer yandan Yunanca konuşan Halkedoncu Ortadoks Hıristiyanları, yani Bizanslıları, siyasi ve coğrafi olarak izole etmişti. Bu durum iki bakımdan önemlidir: Birincisi, Konstantinopolis "Ortodoksluğu"nun dışlayıcı din politikaları ve uygulamaları dinde ayrılığa [skhizma] yol açmış, Süryanice konuşan Hıristiyanlar bölünmüş, Nasturiler İran'a itilmişti. Bu çekişme ve kültürel parçalanma odağının fiilen Darü'l-İslam dışında kalması, diğerlerinin ise tarafgir olmayan bir hükümdarın, yani İslam devletinin yönetimi altında birleştirilmesiyle daha fazla kültürel iş birliği ve etkileşimin yolu açılmış oldu. İkincisi, Bizans'in siyasi ve coğrafi olarak tecrit edilmesi, bu Hıristiyan topluluklarını ve İslam egemenliği altında yaşayan bütün diğer Helenleştirilmiş halkları 
karanlık çağlardan da korudu ve Bizans'ın 7. ve 8. Asırlarda Helenizm karşıtlığına kaymasından etkilenmemelerini sağladı (Gutas, 2003, s. 25).

Dönemin ilim merkezlerini ana hatlarıyla iki grupta ele almak mümkündür. Bunlardan birinci grup, Doğu İslam dünyasındaki (Abbasîlerin) merkezlerdir. Abbasîlerin hâkim oldukları dönemdeki önemli ilim merkezleri olarak şuralar zikredilebilir: Bağdat, Basra, Belh, Buhara, Fergana, Merv, Semerkant, Kûfe, Misır ve Medine. Endülüs ve civarlarında ise Kurtuba, Gırnata, İşbilye, Marakeş (Fas), Tilimsan (Cezayir) ve Kayrevan (Tunus) gibi bilim merkezlerinin varlığı da dikkat çekmektedir (Özkan, 2018). Önemli eğitim merkezlerinin Belh, Nişabur, Buhara gibi doğu noktalarında kurulmuş olmasının nedeni hep farklı şekillerde tartışlagelmiştir. Müslümanların görkemli medeniyet gelişimi, Şam, Bağdat, Kahire, Kordoba gibi şehirleri hem deniz hem de kara rotalarıyla genişleyen ağları sayesinde devamlı irtibat kurabilen kültürel ve ticari başkentlere dönüştürmüştür. 12. asır itibariyle İslam medeniyeti Hıristiyan Avrupa'nın açık ara önüne geçecek şekilde gelişmişti (Turner vd., 1993, s. 27). Bu gelişmeler gözde eğitim ve yükseköğretim ile bilimsel araştırma merkezlerinin belirli şehirlere konuşlanmasına neden olacaktı. $\mathrm{Bu}$ nedenle üniversite örneğine kıyasla bir yükseköğretim merkezi olarak medrese dini eğitim için bir mecra ve Irak-İran gibi bölgelerde İslamiyet’in dini eğitim ayağını yayılabilmesi için bir araçtı.

\section{Dönemin Arap Toplumunun Bilimsel ve Sosyal Alt Yapısı}

İslamiyet’ten önce Arap kültüründe sosyal ilişkiler ağı temel olarak ataerkil ve kabilevari idi. Bu katı yap1 değişmedi ancak onun yerine temelinde kabileci sosyo-kültürel kitleyi yumuşatan İslami üslup yansıtıldı. Emevi halkı da kabaca Arap olanlar ve olmayanlar olarak ikiye ayrılabilir nitelikteydi. İşte bu nedenle Araplar savaş zamanları İslamiyet’i kabul eden diğer milletlerle karşı karşıya kaldıklarında onları "mevâlî" olarak nitelendirmeyi tercih etmişlerdir. "Mevâlî, azat edilmis, köle, sahip, veli, hami, yardımcı, efendi, nimet veren, tabi olan, kendisine nimet verilen, kölenin efendisi gibi anlamlara gelen mevlâ sözcügünün çoğuludur. Bu anlamlardan farklı olarak, İslam'ın ilk dönemlerinden başlayarak Arap kökenli Müslümanlar "hür/özgür" Arap kökenli olmayan müslümanlar ise "mevalî" olarak isimlendirilmis, ve bu kullanım yaygınlık kazanmıșııı” (Aydınlı, 2003, s. 2). Araplar öncelikli, ayrıcalıklı ve önemli siyasi, yönetsel ve yasamayla ilgili işler için kalifiye olarak kabul edilirken, "mevali"den gelenler genellikle göz ardı edilir ve bu türden pozisyonlara çok nadiren gelebilirlerdi. Ancak, II. ve akabinde III. Abdurrahman zamanındaki kültürel, siyasal ve ekonomik gelişmelerle Arap toplumundaki bu "mevali" anlayışı ortadan kalkmıştır (Küskü, 2020, s. 126). Daha önce belirtildiği gibi bu dönemlerde siyasî, idarî ve askerî görevlerin başat olanları ve büyük bir kısmı Araplar’a verilmekle birlikte bunlar, başta şahsî âzatlıları olmak üzere bazı mevâlîye valilik yanında hâciblik, muhafızlık, beytülmâl eminliği gibi devlet işlerinde önemli görevler vermişlerdir. Mevâlînin ilim sahasında ilerlemesinden sonra bunların imamlık ve kadilık görevlerine de getirildiği görülmektedir (Yiğit, 2004, s. 424-426).

İspanya'daki belli araştırma ve ilim merkezlerinin başında Kordoba Camii, Orta Çağ döneminde sağladığı bilimsel imkanlarla ilim adamlarını kendine çeken bir şehir olmuş, yine Kordoba gibi Endülüs'te bulunan Granada ve Murcia şehirleri de bilimsel faaliyette oldukça etkin şehirler olarak sahip oldukları medreselerle de belli bir nüfusu kendilerinde toplamayı başarabilmişlerdir. Bağdad, Şam, Buhara ve Endülüs'ten sonra Misır'daki El-Ezher üniversitesine çok uzak olmayan Nizamiye Medreseleri'nin de ortaya çıkışı ile İslami karakterli belli başlı şehirlerin sosyo-kültürel ve bilimsel kapasitesi oldukça artmıştır. İşte bu şekilde kapasitesi yükselen şehirlerde tıpkı Antik Yunan medeniyetindeki Sofist figürleri ile k1yaslanabilecek türden bir oluşum, yeni bir zümre dikkati çeker olmuştur. Ulema bugün de toplumda sahip olduğu ilim ile diğerlerinden ileri gelenleri tasvir etmek için âlim kelimesinin çoğul hali olarak kullanılan bir ifadedir. Bu uzmanlar sınıfı genellikle, ilim ve bilgi sahibi 'ulema' olarak anılırdı ve terim akademisyen, doktor, bilgin, ilahiyatçı olarak tercüme edilirdi. Aslında bu zümre Arap kültürünün okuryazar hafizasını taşıyan kimselerdi fakat genelleyici bir isim ile tabir edilmeleri kendi aralarında tasniflerinin üzerini örtüp müphemleştirmiştir. Aslında tarih açısından önemli olan şey ortak bir kelime ile terimleştirilmelerinden çok kendi aralarındaki sınıf ve farklardır (El-Azmeh, 1986, s. 251). Ancak bu zümrelerin hangi alanda ne bildiğini meşrulaştıracak bir terimlendirme olmamış olması şemsiye bir terim olan ulema kelimesinin kullanım alanını genelleştirmiş ve genişletmiştir. Ancak ulema kelimesinin mutlaka eğitimli ve belge sahibi eğitmen, akademisyen veya bilim adamı için kullanılıp kullanılmadığı; halk arasında her bilge kişinin ulema şeklinde etiketlenişi ile de yakından ilgilidir.

“Sarayın sağladığı maddi hamilik ve tanınmış şeyhlerin (dini öğreticiler) gözetimi alında bir öğrenim merkezinden diğerine seyahat ederek eğitimini tamamlayan ulema isimli sınıfın ortaya çıkışı, İslami öğrenimde farklı bir sınıfin gelişimine katkıda bulundu (Adas, 1993, s. 45). Medrese kurumu ile doğrudan 
ilişkisi bulunup bulunmadığını bilmediğimiz ulemanın akademik ve bürokratik olarak aldığı görevler inceleme altındaki söz konusu gruba açık olan kariyer seçeneklerine 1şık tutmaktadır. Bununla ilgili bilgiler kendi aralarında da birkaç dala ayrılan dört mesleki kategori altında düzenlenmiştir:

Daimî medreselerde akademik pozisyonlar

Avukatlık ve hukuki meslekler

Din görevliliği

Bürokratik meslekler (Ephrat, 2000, s. 104). Bu dönemde yaşayıp adı ulema olarak geçen sınıf açısından ilim adamları ve siyasetçileri birbirinden ayırmakta fayda vardır zira dönemin siyasi olarak önde gelen her isminin ilimle ilgilendiği düşünülemez.

\section{Medrese Eğitim Kadrosu}

\section{Müderrisler}

Arapça'da medrese öğrencilerin öğrenim gördüğü yer veya öğrencilerin içinde yaşayıp okuduğu bina anlamina gelmektedir. Bu akademik kurumlardaki akademisyenlere ise müderris denir (Kazıc1, 2010, s. 302). Ancak İslam tarihinde bu terimin ortaya çıkışının medrese ile alakalı olup olmadığı tartışma konusudur. Müderrislik ilk dönem İslam kurumalarında "muallim" ve "üstad" gibi sıfatlarla, ancak sonrasında 5. (11.) asırdan itibaren müderris olarak adlandırıldığı gibi yalnızca fikıh dersi verenler için müderris ifadesinin; Kur'an, hadis, nahiv ve tasavvuf gibi ilimlerde eğitim verenler için "şeyh" ifadesinin kullanıldığına dair görüşler mevcuttur. Nizamiye medreselerinin kuruluşu ile sözcüğün burada kullanımı ona resmi bir hüviyet kazandırmıştır (Yılmaz, 2017, s. 144). Günümüz şartlarıyla mukayese edilecek olursa bu kurumlarda oldukça ileri sayllabilecek imkânların öğrenci ve eğitmenler için mevcut olduğu görülebilir. Örneğin, öğrenci başına bugün dört ritl (yaklaşık 3. 250 gr.) ekmek ve et ihtiyacı için aylık bir koyun tahsis edilmiş, ögrrencilere istedikleri hocadan ders alabilme gibi bir imkân tanınarak daha iyi yetişmeleri temin edilmiştir. Farklı hocalardan istifade etmek amacıyla başka şehirlerden davet edilen hocaların bilgi birikimi ve tecrübelerinden istifade etmeye çalışılması ve müderrislere ilk defa maaş bağlama örneğinin bu medreseler çatısı altında yaşanması (Ocak, 2012, s. 2199) da Nizâmiyeleri çağdaşlarından ayıran özelliklerdendir.

Medrese sisteminde hem öğrenciler hem de öğreticiler arasında hiyerarşi söz konusudur. Aslında müderrisler arasında farklı eğitsel sorumluluklara tekabül eden farklı unvanlar vardı. Eğitimciler, müid, müfid veya müderris/dersiam gibi isimlerle çağırılırdı (Anameriç ve Rukancı, 2008). Ayrıca eğiticiler için molla, allame, kari, muhaddis ve fakih gibi unvanlar da kullanılırdı ve bunların her biri medresenin eğitsel sisteminin yapısı içinde farklı görev ve faaliyetlerle sorumluydular. Yine bu unvanlar arasında bu kurumlar içindeki görev ve sorumluluklarına bağlı olarak bir gruplama yapmak ve önem sırasına göre şöyle birtakım detaylandırmalar yapmak mümkündür. Örneğin; müderrisin esas görevi medresedeki eğitim-öğretim faaliyetlerini yürütmekti. Medresenin vakıf gelirlerinin toplanması, maaşların ödenmesi gibi idari işler için özellikle büyük medreselerde başka görevliler bulunmaktaydı. Fakat bu durum her medrese için geçerli değildi. Medrese vakfedildiği sırada medrese için müderris, nazır, mütevelli gibi görevliler ayrı ayr1 tayin edilmiş olabileceği gibi, bu görevlerden bazılarının hatta bazen bütün görevlerin tek bir kişiye verildiği de olabiliyordu (Yılmaz, 2017, s. 147).

Medresenin başındaki kişi yani müderris medresenin idari işlerini yürütür ve tıpkı öğretmenler gibi çoğu lonca üyesi öğrencilerle ilgili işleri yapardı. Hem öğrenci hem de eğitmenler medrese içinde yaşardı. Müderrisin sıklıkla kadının veya kâtibin görevlerini yerine getirdiği de olurdu. Müderrisin görev kadrosu değişkenlik gösterebilirdi ancak Nizamiyedekiler hariç genellikle ömürlük bir kadroydu. Geniş medreselerdeki müderris odası oldukça önemliydi ve oda sahibi eğer bir akademisyen olarak biliniyorsa, onun gözetimi altında çalışmak için çok uzak yerlerden öğrenciler gelirdi. Aralarında nadiren de olsa kadın öğrenci ve eğitmenler olurdu (Fisher vd., 1968, s. 217). Müderrislerin hangi dersleri okutacaklar1 da medrese vakfiyelerinde yazan bilgiler arasındadır. Bağdad Nizâmiye Medresesi'nde fikıh, ilahiyat ve edebiyat derslerini veren kişiler bilinmektedir. Konya Karatay Medresesi vakfiyesinde ise müderrisin şerîat, hadîs, tefsir, usûl ve furû’l ilimlerinde (fikhın tatbiki kısımlarını içeren ilimler) liyakatli ve ehliyetli olması hususu öngörülmektedir (Gül, 1997, s. 13).

Hangi medresede ne alanda eğitim alındığından çok hangi ulema ile hangi kitapların çalışıldığı daha fazla merak edilen bir meseleydi. Hatta danışacak bir hocaya veya yetkin bir âlime sahip olmak önemliydi. 
Örneğin; Celaleddin es-Süyûtî (ö.1505), otobiyografisinde, entelektüel meşguliyetin farklı alanlarındaki başarılarını geniş bir şekilde sayar. Listesinin sonunda tıbbın yanında kıraat ilmini zikreden Süyûtî, bu alanda hiç hocası olmadığı için onu öğretmeye cesaret edemeyeceğini belirtmiştir. Problem Süyûtînin eğitimsiz olması değildir- aksine bu konuda bir kitap bile yazmıştır- fakat bilgisini herhangi bir muteber âlime dayanarak gelecek nesillere aktaramıyor oluşudur (Berkey, 2014, s. 33).

Medresede eğitim vererek kazanılan paraya gelince, bu miktar ders döneminin başında, en başından belirleniyor ve ödenecek para miktarına öğrenciler karar veriyordu. Medreselerin yayıllşından sonra bile medreselerdeki eğitmenler öğrencilerden eğitim ücreti kabul ediyordu ki bu oldukça eleştirilen bir durum olmuştur. Öğrenciler ücreti ödemeden derslere kabul edilmezdi. Ancak medreselerin gelirleri genellikle öğrencilerin velilerinin zenginliğine bağlıydı. Yani eğer medrese öğretmeni veya profesörler varlıklı ve yüksek sınıftan bir ailenin çocuğuna eğitim veriyorsa bu iyi kazandığı anlamına geliyordu. 13. asırda Dımaşk medreselerinin vakfindaki bazı kayıtlara göre öğretmenlere dirhemle ödeme yapıldığı gibi buğday ve arpa çuvalları gibi ölçütlerin de maaş ödemelerine dâhil edildiği; verdiği dersler karşlloğında doğrudan şehrin melikinden maaş kabul eden müderrisler olduğu da bilinmektedir (Yllmaz, 2017, s. 148).

\section{Müderris Yardımcıları: Muîdler ve Müfîdler}

Müderrislerle birlikte söz konusu kurumlarda adı geçen bir diğer görevli türü de muîdliktir. Hiyerarşik olarak müderrislerden sonra gelen muîdler, müderrisin verdiği derslerin tekrarını yapıp öğrencilerle birlikte konunun üzerinden geçmekle görevliydi. Müderrisin dersini takiben muîd devreye girer ve tekrar yaptırırdı. Eyyübi ve Memlük döneminde Misır'daki eğitimi değerlendirip tahlil eden Abdu'l-Gani Mahmud Abdu'lÂtî, "Muîd"in vazifelerinden bahsederken onun, hocaya bir seferden fazla soru soran talebenin, anlayamadığı konuları ve sorularını açıklayıp cevaplandırdığını söyler. Böylece hocadan (müderris) başka, talebe ile daha yakından ilgilenen ve bir çeşit asistan olarak kabul edebileceğimiz muîdin, talebe ile daha rahat konuştuğunu belirtir (Kazıc1, 2010, s. 28). Medrese bünyelerinde sık rastlanan görevlerden muîdlik vasfının ne zaman ortaya çıktığına dair farklı görüşler vardır:

"Bu vazifenin, hicrî V. Asırda (XI. asır) ortaya çıktığı görüşü hâkimdir. Araştırmacıları bu görüşe sevk eden âmil bu tarihten önce, kaynaklarda ona ait bir kaydın izine rastlanmamış olmasıdır. Muîdlerin vazifelerinin medrese bünyesinde ortaya çıkma sebebinin, medreselerin öğrenme kabiliyetleri birbirinden farklı çok sayıda öğrenciyi bir araya getirmesi olduğu da düşünülmektedir. İşte, muîdlerin görevi değişik kabiliyet seviyesindeki öğrencilere yardımcı olmak ve onları diğerlerinin yani ortak seviyenin mümkün olduğu kadar yakınına taşımaktır" (Çelebi, 1983, s. 258). Ancak bu vazifenin daha önceki dönemlerde mescitlerde de bulunduğuna dair görüşler mevcuttur: "Hâlbuki bu, bizzat fikıh eğitimine özgü bir görevdi, yoksa içinde bu ilmin öğretildiği kurumlara değil. Örneğin, Ebü’t-Tayyib et-Taberî̀nin fikıh öğrencisi olan Ebû İshâk eş-Şîrâzî, Nizamiye Medresesi kurulmadan çok önce, Taberî Mescidi'nde onun muîdi olmuştu" (Makdisi, 2015, s. 285).

Muîllik bir açıdan gerekli eğitimlerden geçerek ilmî ehliyetini ispatlamıs, fakat münhal bir mansıb bulunmadığından veya başka bir sebepten dolayı müderris olarak bir medresede görev yapmayan müderris adayları için müderrisliğe ara bir geçiş kademesiydi. Bununla birlikte bir medresede müderrislik sahibi olmadan bütün öğretim hayatını bir medresede muîd olarak geçirmiş olanlar da vardı (Yılmaz, 2017, s. 152153). Aslında bir çeşit stajyerlik olarak da düşünebileceğimiz muîdlik, vazifeyi yerine getiren kişiye hocasının yanında daha fazla bulunarak ondan daha fazla istifade etme olanağı da tanıyordu. Muîdlik, ücretli olduğu kadar gönüllü bir görev de olabildiği gibi bu kadroya sahip olmayan yani bu kadroyu teşkilatında zorunlu tutmayan medreseler olduğu da bilinmektedir.

Ayrıca müderrislerin müfîd adında yardımcıları daha olurdu. Başlangıç seviyesindeki veya kendinden alt seviyelerdeki öğrencilerin, dersleri konusunda yardım almak için kendisine başvurabilecekleri ihtisas aşamasındaki bir öğrenci ya da eğitimini tamamlamış bir yetişkin bir fakîh/müftî idi (Makdisi, 2015, s. 287). Müfidler de fikıh, hadis ve Kur'an ilimlerinde çalışanları nitelerdi. Medreseler bünyesinde düzenli bir kadro olmakla birlikte bu kimseler, dersler konusunda zorlanan öğrencilere sağladığı yardımın yanı sıra ön plana çıkan ilmi donanımları sayesinde zor meseleler konusunda diğer ihtisas ögrencileri ve âlimlere de istek doğrultusunda yardımcı olurdu.

\section{Medrese Öğrencileri}

Öğrenci ve hocalar için kullanılan kelimeler zorunlu olarak bir medresede mansıp sahibi olma anlamı taşımamaktadır. Tam zamanlı ilimle meşgul bir öğrenciyi ifade etmek üzere sabit ve özel bir terim yoktur. Tilmiz kelimesi bir medresenin değil bir hocanın talebesi demektir. Talib (ç. talebe) ise ilim tahsil etmek 
isteyen kişi demektir ve her zaman olmasa da çoğu kez hadis ilmiyle meşgul olanlar için kullanılır. Talebe bir öğrenci grubudur fakat ilgili kayıtlar bu grubun belirli bir medresede kalanları değil, ilim tahsilinde bulunmak isteyenleri temsil ettiğini göstermektedir. Öğrencileri ifade etmek için müstefídûn (istifade edenler), müştegilûn bi'l-ilm (ilimle meşgul olanlar), müteallimun (öğrenenler) ve mütefakkih (fikıh tahsil etmişler) gibi terimler de kullanılmıştır. Fakat bu terimlerin hiçbiri medreselerde tam zamanlı bir öğrenimi ifade etmezler ve zaman zaman medreselerde kalan genç öğrenciler dışındaki kişiler hakkında da kullanılmışlardır (Chamberlain, 2009, s. 104). Öğrencilerin aldığı eğitim, seviyelerine göre değişiklik gösteriyordu ve sınıflandırılmış yani aşamalı bir sistem içinde ilerliyorlardı. Anadolu Selçukluları döneminde bir medresede, 20-40 arasında öğrenci öğrenim görmekteydi ve öğrenciler Mübtedî, Mülâzım ve Fakîh olmak üzere üç gruba ayrılmıştı. Medrese eğitimine yeni başlamış öğrencilere Mübtedî; orta seviyedeki öğrencilere Mülâzım, ileri seviyedeki öğrencilere ise Fakîh adı verilmekteydi (Özkan, 2007, s.80). Osmanlı medreselerinde ise öğrencilere "talib/talebe, fakih, mülâzım, tüllab, dânişmend, sûhte, softa ve müsteîd" gibi isimler verildiği görülmektedir. Bu kavramlardan her biri genel olarak öğrenciyi belirtmekle beraber, aralarında bazı seviye farklılıkları bulunmaktadır. Örneğin; "Mübtedîler" olarak da ifade edilen ve medreselerde başlangiç seviyesinde öğrenimlerine devam eden öğrenciler için "sûhte", daha ileri düzeyde olanlar için ise "dânişmend" kavramının kullanıldığı görülmektedir (Aydın vd., 2018, s. 176). Bu nedenle öğrencileri nitelendirmek için kullanılan ifadelerin kullanıldıkları dönemlere göre değişkenlik göstermiş olduğu akılda tutulması gereken bir konudur.

\section{Medrese bünyesinde öğrenci profilleri}

Makdisi Orta Çağda skolastik camiayı incelediği çalışmasında medrese öğrencilerine yönelik yaptığı bir gruplama ile (2015, s. 257-262) sınıflandırma sunmaktadır. Araştırmacı eğitim seviyeleri, medreseden aldıkları burs, vakıf lehdarı olmaları ve sınıftaki konumları açısından öğrenciler için aşağıdaki başlıklardan oluşan şu gruplamayı yapmıştır:

- Eğitim sevijelerine göre: Bu kriter öğrenime göre geldikleri seviyeye işaret eder.

Müptedî: Başlangiç seviyesinde öğrenci

Mutavassit: Orta seviyeli öğrenci

Müntehî: Üst seviyedeki öğrenci

- Medreseden aldıkları bursa göre: Bu kriter aldıkları bursun miktarı ile ilgiliydi.

Konya'da İplikçi (Altun-aba) Medresesi'nin 598 (1202) tarihli vakfiyesine göre burada müderris, muîd, imam, müezzin, ferrâş (hademe) gibi görevliler ve başlangiç, orta ve ileri seviyede olmak üzere üç tür öğrenci grubu bulunmaktaydı. Şemseddin Altun-Aba, medresenin masraflarının karşılanması için yakınlarındaki bir han, hana bitişik on sekiz dükkân, ayrıca şehrin çeşitli yerlerinde otuz kadar dükkân bağışlamış, Konya civar köylerinden de arazi vakfetmiştir. Bu gelirlerden müderrise 800, muîde 240, medrese camisinde namaz kıldıran imama 200, müezzine 100, ferrâşa 60 dinar yıllık ücret ödenmekte, ayrıca ileri seviyede bir ögrenciye ayda 15 , orta seviyedekine 10 ve ilk seviyedekine 5 dinar verilmekte, medreseye kitap alımı için her yıl 100 dinar ayrılmaktaydı (Turan, 1947, s.202-203; Gül, 1997, s. 13). Yine Gül (1997, s. 13)'e göre Osmanlı öncesi Anadolu medreselerinde öğretim parasızdı çünkü sultanlar, varlıklı kimseler veya hâtûnlar vakfiyeleri olan medreseler kuruyor giderler kadar gelir kaynakları da açıkça belirtiliyordu.

Vakıf Lehdar Olmalar İtibariyle: Bu açıdan da öğrenciler Mütefakkih (çoğulu: mütefakkie) ve Fakîh (fukahâ) öğrenciler olmak üzere ikiye ayrllıyordu. Mütefakkih kendini fikıh öğretimine adayan kişi anlamına gelmekle birlikte; Fakîh, hem ihtisas aşamasındaki hem de ihtisasını bitirmiş yetişkin bir müftîyi ifade etmek için kullanıliyordu. Vakıf lehdarı olmaları anlamını bu gruba atfeden durum ise söz konusu medreselerin fukahâ ve mütefakkihler için kurulmuş ve onlar için vakfedilen eğitim kurumları niteliğini taşımasıydı. Medreseler bu türden öğrenci sayı kapasitelerini sınırlı tutabiliyordu.

Simftaki Konumlarna Göre: Sadece derse katılan “dinleyici” öğrenci için müstemi terimi kullanılırken, derslerde yürütülen faaliyetlere bilfiil katılan ve ihtisas düzeyinde özel çalışmalar yapan aktif öğrenci için müşteğil terimi kullanıllyordu. Yani çalışan öğrenci gibiydi. Müştegil aldığı maaş itibarıyla müstemi’den daha üst konumdaydı (Makdisi, 2015, s. 257-261). 
Öğrenciler hem dürüst hem de dikkatli katılım gösteren kişiler olmalıydılar aksi takdirde medresenin onlara verdiği bursu hak etmemiş olurlardı. Hatalı davranış sergilemek dışında, ders süresi içinde başka bir öğrenci ile konuşup Kur'an ezberini ihmal etmek veya söylenenleri dinlememek hakareti hak etmek demekti. Bu kişi hem görevini ihmal etmiş hem de arkadaşını görevini yerine getirmekten alıkoymuş oluyordu. Medreselerde öğrencilere hem yaşama alanı hem de harçlık veya burs sunulması oldukça avantajlı bir durumdu. Nizamiye medreselerinden önce bu durumun var olup olmadığ1 kesin olarak bilinmese de "medreselerde öğrencilere harçlık yani tullab ve medresede ders verenlere haftalık ücret verilmesine yönelik uygulama muhtemelen Nizâmü'l-Mülk tarafından başlatılmış olabilir” (Fisher vd., 1968, s. 2017).

\section{Akademik Detaylar \\ Müfredat ve Öğretim Yöntemleri}

Yükseköğrenim kurumlarının müfredatı Arap dili ve edebiyatı, Farsça, Kur'an, Hadis, Fıkıh, Kelam, Mantık, Astronomi ve Matematikten ibaretti. Bu dönemde doğa bilimleri ve felsefenin çeşitli ekolleri öğretim içeriğine dâhil değildi fakat daha sonraları Babürler döneminden (16.-19. asırlar arası) sonra bu konular ve daha fazla seküler kökenli konu içeriğe dâhil edilmiştir (Alavi, 1988, s. 9).

Orta Çă̆ İslam dünyasında öğrenim konuları iki temel kategoride incelenebilir: "Eskilerin Bilimi" yani Ulûmü'l-Evâil ve İslami Bilimler. Bahsi geçenlerden ilki yabancı ve İslamiyet öncesi kökenli, matematik, astronomi, jeodezi, fizik, tıp, gramer, felsefe gibi ilimleri ihtiva ederdi. Bu ilimlerin ögreniminin yapıldığı yerler Dârü'l-ilm olarak adlandırıldı. İkincisi ise Kur'an tefsiri ve çalışmaları, ritüel, şer'i hukuk ve hadisler gibi teolojinin farklı branşlarından ibaretti. Bu bilimler büyük miktarda tamamlanmış doktrinler ve Sünnete veya dini meselelerde Sünni geleneklerine dayanan devasa bir dini, ahlaki, hukuki ve sosyal öğreti koleksiyonunu oluşturmuştur (Creswell, 1922, s.1). Dini eğitim Arapça'da Ulûmü’l-evâil olarak nitelendirilen ve öncelikle Kur'an bilimleri, hadis bilimleri ve fikıhtan oluşuyordu. Aktarılan yani iletilen dini ilimlere ek olanlar mantık, felsefe, matematik ve doğa bilimlerini içeren Ulûm-i Akliye (deneye bağlı ilimler/ akıl ilimleri) idi. İkinci gruba, büyük ölçüde Yunan kökenini ima etmek için "yabancı ilimler" veya "eskilerin ilimleri" de denilirdi (Afsaruddin, 2005). "Arapların ilimleri" , "nakil ilimleri" ve "dini ilimler" ifadeleri, dil bilgisi sözcük bilgisi, dini hukuk, Kur'an tefsiri ve felsefi teoloji gibi dil bilimsel ve dini disiplinler için kullanılırdı (Ferngren, 2013, s. 76). İslami ilimler ile birlikte medreselerde Sosyal Bilimler de çalışllyyordu. Sosyal Bilimler daha rasyonel bir ders grubu olarak görülmekle birlikte daha çok eskilerin ilimleri olarak görülen Yunan karakterine sahip ve deneyimlemeyi ön planda tutan bilim gruplarının genel adıydi.

Medrese bir kurum olarak, 4. asırdan 10. asra kadar İran'da izi sürülebilmesine rağmen Sünni İslam fikhının dört mezhebinden biri veya daha fazlasının, Arapça dil bilgisi, Kur'an tefsiri ve hadisler de dâhil olmak üzere eski İslami bilimler ile birlikte öğretilmesine adanmıştı. Bunların yanı sıra tarih, edebiyat, belagat, matematik ve astronomi gibi daha seküler disiplinler İslami coğrafyalarında 5. Asırdan itibaren 11. asra kadar çoğalmaya başlamıştı (Mortel, 1997, s. 236). 'Eski ilimlerin 'ne zaman medrese, cami veya hangahlara taşındığı bilinmemektedir. En azından Anadolu Selçuklularda, Abbasi Bağdat'ında, Artuklularda ve Zengi Kuzey Irak bölgesi ile Eyyübî Şam ve Kahire'sinde 12. asırda bunlardan bazılarının okutulan ilimler arasında olduğu bilinmektedir. İran gibi diğer bölgelerde Selçuklu hükümdarlı̆ı̆ndaki gibi olmasa da sonra gelen İlhanlılar döneminde benzer bir gelişime şahit olunmuştur. Bu hareket üç şekilde gerçekleşmiştir- bunlar kütüphane için el yazmalarını çoğaltmak, öğretmek ve böyle bir kurumun sınırları içinde veya başka bir yerde bir medrese hocası eşliğinde bu esere çalş̧mak, son olarak da belirli disiplinler için özel bazı bölümlerin eseri bağışlaması şeklindedir (Halm, 1997, s. 71).

Yazarların bazen Avrupa kolejlerinin bir eşdeğeri olarak tasvir ettiği medrese bu noktada bir "enstitü, bir kurum" haline dönüşmüştür çünkü aktiviteleri sabit bir müfredat, lokasyon, düzenli saatler, öğretim metodolojisi ve mezuniyet sistemi ile yakından düzenlenip yapılandırılmıştır. İşte tam bu nokta, evvelki yöneticilerin aksine devlet otoritelerinin güçlü bir sosyal ve politik araç olarak yüksek eğitime verdiği önemi açıklar niteliktedir. Personel alma, müfredat belirleme ve medreselerin finanse edilişindeki artan devlet katılımı medreselerin o dönem Sünni bürokrasi için iş gücü yetiştiren mesleki okullar olarak hizmet veren bir devlet dairesi olduğu teorisini ortaya koymuştur (Fisher vd., 1968, s. 216). O dönemde medreselerde eğitimin programlanışı veya müfredat konularındaki dağılmanın daha çok medrese sahibi veya kurucusu ile ilgili olduğunu biliyoruz. Bu açıdan hemen her medresenin kendi müfredatını ve buna bağlı eğitim programını düzenlemek konusunda nispeten serbest olma ihtimali de akılda tutulmalıdır. 
Abbasi Halifeliği zamanına gelindiğinde hali hazırda çok sayıda medrese mevcuttu ve her birinde kullanılan teknikler değişkenlik gösteriyordu. Ancak temel bazı teknikler vardı. Medreselerde temel olarak dönemin otoriter bilim adamları ve filozofları tarafından geliştirilen tümdengelim yöntemi vardı. Problemler bu otoritelere dayalı olarak çözülmeye çalışılırdı. Bu yaklaşım şunları içeriyordu:

Ez̧ber ve tekrar: Hafızayı güçlendirmek için ve ezberde iyileşme için yapılırdı, derin ezber bilgisine sahip kişiler bahr'ul ilm yani bilgi denizi olarak adlandırılırdı.

Kavrama: Önceki tekniklerin oturtulması içindi.

Müzakere: Meclis içindekilerle fikir alısverişi, soru-cevap ile yapilırdı.

Not alma: Ezberlenen konunun yazılması elzemdi ancak kitapların yaygınlaşması ile birlikte bu metot kaybolmaya yüz tutmuştu (Anameriç vd., 2008; Makdisi, 1981).

Bahsi geçen çoğu seküler bilim Sosyal Bilimler olarak yorumlanabilir: "Yahudi din okullarına ve Hıristiyan heykeltraş okullarına göre medreseler, Kur'an'ın ezberlenmesi, doğru dini ibadet bilgisi ve (fikıh) kitaplarından şer'i mevzularda çıkarımlarda bulunma üzerine yoğunlaştılar ve aslında en sonunda ilmi kanunlar bütününü oluşturmuşlardır. Felsefe, astronomi, matematik İran medreselerinde de öğretiliyordu fakat felsefi çalışmalara zıt olarak Arap toprakları arasındaki zıtlaşma büyüdü ve 14. asırdan sonra Arap medreselerinde bu bilimler yerine dini hukuk ile birlikte dil bilgisi ve hitabet dersleri ön plana çımaya başladı. Tipik olarak, ders veren kişi uzun cümleler dikte eder ve öğrencilerin anlam, içerik ve üslup açısından yorumlarda bulunmalarını isterdi (Campo, 2009, s. 446). Bilindiği gibi İslam eğitim sistemi içinde yorumlama ve çıarımda bulunmanın sık başvurulan yöntemlerdendi.

\section{Medreselerin Finansal Yönetimi}

Medreseler 11. asırda ortaya çıktığı zaman ve devlet yönetimini elinde tutanlar medreseleri ideolojik propaganda merkezleri olarak kullanmaya başladığında işler değişti. Medreselerin ortaya çıkışı eğitim sisteminin mesleki yapısını bir bütün halinde değiştirmiştir. Bu değişim medreselerin yalnızca işleyişindeki bazı şeyleri değil aynı zamanda yönetim ve finansmanına da yansımıştır. Medreselerin finansmanı özel girişimden kaynaklanmış ve bu durum Orta Çağ boyunca bu şekilde devam etmiştir. Medresedeki veya bir camideki yükseköğretim çok sayıda farklı kaynaktan ancak genellikle evkaf gelirleri ile finanse edilirdi. Medreseler gibi yükseköğretim kurumları hayır kurumlarının alanına girdiğine, bazı farklı uygulamalarının İslamiyet’te özgür düşünceyle çatıştı̆̆na dair birtakım imalar vardır. Başka bir deyişle, medreselerdeki eğitimcilerin geçimleri özel hayır sahiplerine bağlıdı. Bu hayır sahipleri oldukça etkili bir şekilde yevmiye miktarlarını ve yönetimi dikte edebiliyor ve aynı zamanda da müfredat içeriğine karışarak eğitimcilerin kendi müfredatlarını, okutacakları kitapları ve birlikte çalş̧acakları öğrencileri kendilerinin belirlemelerine izin vermiyorlard1 (Shatzmiller, 1993, s. 312).

Bir kez vakıflaştırıldığında, o mülk artık devrolunamaz ve elden çıkarılamaz hale geliyordu. Herhangi bir satışa, depozitoya, ipoteğe, hediyeye, mirasa, haciz ve elden çıkarmaya her ne sebeple olursa olsun tabi olamazdı. Ancak bir istisna dişında: eğer vakfin kurucusu vakıf kurulurken öyle şart koşmuşsa veya istibdale tabi asıl mülk harap olup kullanılamayacak hale gelirse ve böylece artık vakfin hedefleri gerçekleștirilemeyecek olursa eş değer bir mülk ile takas edilebilir, satılabilir veya başka bir konutun fiyatına denk gelecek şekilde zorunlu olarak yeniden yatırıma tabi olabilirdi (istibdal) (Makdisî, 2015, s. 81). Medreseler finansal problem yaşadıklarında veya artık varlıklarını maddi olarak idame ettiremez hale geldiklerinde kolaylıkla form değiştirebiliyorlardı. Örneğin bir medrese camiye çevirilebiliyor, eğitmeni ise caminin imam veya müezzini oluyordu. Bu konuda Chamberlain (2002, s. 79), Cezeri'nin verdiği bir örnekten alıntı yaparak 697/1297-8 yllında yaşanan benzer bir olaydan bahsetmektedir: Mu' azzamiye isimli medrese eğitmeni "medreseye dönüşen caminin" imamı olur.

Vakfa devredilen mülk ve gelirler yani yapılan hayırlar bir mütevelli (yönetici veya vekil) tarafindan yönetiliyordu. Mütevelli medresenin kurucusu tarafindan atanırdı ve onun ölümünden sonra herhangi bir ihtiyatla düzenleme yapılmadıysa kadı devralırdı (Fisher vd., 1968, s. 217). Zengin vd. (2016, s. 153)'e göre ise tamir, temizlik, aydınlatma ve su hizmetlerine ek olarak temizlik, tefriş ve aydınlatma ve su hizmetlerine ilişskin oldukça geçerli miktarda bilgi de çeşitli medreselerin vakfiye kaydında mevcuttur.

\section{Medrese Binalarının Fiziksel Özellikleri ve Öğretime Yansıyan Yönleri}




\section{DEMIR}

"Medresenin resmi statüsü ile dini ve eğitsel bir kurum olma görevinin birleşmesi mimari yapısı tarafindan da doğrulanmıştır. Bu yapı şekli, belirli fonksiyonel ihtiyaçlarla zorunlu hale gelen bazı modifikasyonlar eşliğinde hem sarayvari hem de sivil mimariden eşit derecede beslenmiştir" (Tabbaa, 1997, s. 129). Erken dönem medreselerin en yaygın prototipi dört eyvanlı medreselerdir. Geleneksel olarak medreselerin öğrencilere konaklama, iş gibi bazı temel ihtiyaçlar konusunda destek sağladığı düşünülse de günümüze kadar gelmiş mevcut örnekler bunun medreseler açısından bir kural olmadığını ve medreselerin ileriki dönemlerinde öğrenciler için bu tesis ve imkânların yaşamın gerekliliği olarak medrese dizaynının bir parçası haline geldiği görülebilir. Medreselerin etrafında küçük bir cami olurdu; bu cami hem öğretim hem de öğrenim için inşa edilirdi. Dört eyvanlı cami planı; başka bir deyişle, artı şeklinde plan bahsi geçen dönemler içinde en fazla tercih edilen plandı ve görünüş itibariyle oldukça eski bir kullanıma sahipti. Ayrıca sivil binalardan dini mimari yapılara aksetmişti. "Dört eyvanlı meskûn medrese hem çok erken hem de çok yaygın bir formdur. Gazne yakınındaki Laşgari Bazar bölgesindeki kazılarda Gazneli sultanların dört eyvanlı saray avlusu kazılmıştır. Haç şeklindeki bina planı Mısır'da ikâmete tabi binalarda da görülmektedir. Fustat'ta yapılan kazılar 11. asır kalma bir grup evin çok küçük nüanslarla açık bir avlunun etrafinda dört eyvana sahip olduğunu gün yüzüne çıkarmıştır (Kuban, 1985, s. 35). Bu ifadelerden dört eyvanlı modelin medreselerin ortaya çıkışından çok daha öncelerde dahi sivil mimaride sıklıkla tercih edilmiş erken bir model olduğu anlaşılmaktadır.

Dört eyvanlı model aslında Sünni ekollerin bir sonucu olarak ortaya çıkmıştır ve eyvanlanın her birinde genellikle başka bir ekolün dersleri işlenmiştir. "662 Senesinin başlangıcında Safer ayının 5'inde aynı yıl (Miladi 9 Aralık 1268) yeni bir okul hizmete girmiştir. Bu okulun 4 eyvanında 4 farklı ekolün dersleri işlenmiştir: Şafii yöntemi dördüncü eyvanı meşgul etmiş; bir Hanefi şeyhi kuzey eyvanında ders vermiş; Abdülmü'min b. Halef Dimyatî Hadis üzerine yorumlarını doğu eyvanında yapmış; başka bir fakih yedi farklı Kur'an kıraati dersini batı eyvanında gerçekleştirmiştir. İşte bu nedenle sahanlık boyunca mevcut dört eyvan artı biçiminde planlanmıştır (Creswell, 1920, s. 39).

\section{Tartışma, Sonuç ve Öneriler}

Medrese bileşenleri, İslamiyet'in ilk yıllarında cami halkalarının içinden doğmuş, önce mescit kısımları sonrasında ise ayrı binalarda eğitim verilmeye başlamasıyla daha belirgin hale gelmiştir. Her ne kadar medreselerin veya medrese olarak anılan bazı yapıların emsallerinin İslamiyet'ten önce de var olduğunu ileri süren savlar var olsa da medresenin -en azından bildiğimiz tanımıyla- geçerli olan kapsamı İslamiyet içinde müteşekkil olmuştur. Medrese çatıları altında çalışılanlar, zamanla içtihat dışına da taşan öğretim konularını, sosyal bilimleri de içine alarak genişlemiş ve medreseler çeşitli müslüman devletlerin siyasi politikalarının eğitime yansımasına da mekân teşkil etmişlerdir. İslami ekollerin medreselerin şekillenişinde etkisi büyüktür ve bu kurumlar, İslam medeniyetlerinin birbirlerine karşı fiziki olduğu kadar ilmi mücadelesinde aktif rol oynamış; aynı zamanda İslamiyet'in farklı coğrafyalara yayılışına da büyük katkı sağlamışlardır.

Tablo 1. Medrese Prototipleri Üz̧erine Tartısma

\begin{tabular}{|c|c|}
\hline Medreselerin Prototipleri & Tartışma \\
\hline $\begin{array}{l}\text { Medrese, dini kurumların içinden } \\
\text { çıkmış, ibadethanelerin ilim için } \\
\text { bölünen odalarından tek başına } \\
\text { kurumsallaşmaya doğru yol almıştır. }\end{array}$ & $\begin{array}{l}\text { Bu durum Batı'daki Kilise içinden doğan dini eğitimin kilise ve katedral okulları ve } \\
\text { münzevi hayat yaşayan Hristiyan keşişlerin kurdukları manastırlardaki gibi medrese } \\
\text { de dini boyutun bizzat merkezindedir ve dini eğitim ağırlıklı karaktere sahiptir. }\end{array}$ \\
\hline $\begin{array}{l}\text { Medreselerde mezhep veya içtihadi } \\
\text { ekollerin etkisi asırlar boyunca oldukça } \\
\text { yoğun hissedilmiştir. }\end{array}$ & $\begin{array}{l}\text { Örneğin, Müslümanlık ortak paydasında buluşmalarına rağmen Şii Fatimiler ve Sünni } \\
\text { Abbasiler arasında hem siyasi hem akademik rekabet oldukça belirgindi. Hıristiyan } \\
\text { dünyasında dini karakterli de olsa yüksek ögrretim olarak ele alabileceğimiz } \\
\text { manastırlarda da tarikat olgusu belirgin izler bırakmıştı. Ayrıca manastırlar içinde } \\
\text { çeşitli zamanlarda çeşitli reformlar gerçekleştiriliyordu ve bu reformlar manastır dini } \\
\text { ritüelleri ve eğitim uygulamalarında etkili oluyordu. }\end{array}$ \\
\hline $\begin{array}{l}\text { Genel olarak sıralamak gerekirse } \\
\text { medreselere etki eden faktörler } \\
\text { arasında devlet yönetimi, baskın } \\
\text { tarikatlar ve bunların mensubu } \\
\text { ulemanın eğitim-öğretimdeki görüş ve } \\
\text { uygulamaları, vakıflar ve yönetsel } \\
\text { uygulamaları sayılabilir. }\end{array}$ & $\begin{array}{l}\text { Nizâmiye medreselerinde olduğu gibi devlet yönetimi, açılan medreselerin hangi } \\
\text { doktrin üzerine eğitim-öğretim sağlayacağını belirleyebiliyordu. Müderrisin hangi } \\
\text { eserleri okuttuğu gibi meselelerde medreseyi kurmuş olan vakfin eğitim-öğretim } \\
\text { süreçlerindeki etkisi oldukça hissedilir boyutlardaydı. }\end{array}$ \\
\hline $\begin{array}{l}\text { Medrese teşkilatı içinde eğitim-öğretim } \\
\text { ile sorumlu kişiler (toplumdaki sınıf } \\
\text { olarak ulema, kadro meşgul eden }\end{array}$ & $\begin{array}{l}\text { Medrese bugünün eğitim sistemlerinde olduğu gibi kurumsal kimliği içinde eğitim- } \\
\text { öğretime ait ögelerin yanı sıra yönetsel birtakım uygulamaları da barındırıyordu. } \\
\text { Tercih edilen müderrislerin istihdamından okutulacak eserlere kadar hemen her }\end{array}$ \\
\hline
\end{tabular}


kimseler olarak müderrisler ile destekleyici kadrolar) ve idareciler olarak iki sınıf görev almıştır. Bu kişilerin varlığ hem fiziki hem de akademik bir yapı olarak medresenin iç dinamiklerini derinden etkilemiştir.

Müfredat "Eskilerin Bilimi" yani antik dönemden o döneme kadar ilerleyen çalışma alanlarını ve İslam ilimlerini içermiştir. Medrese Antik Dönem Yunan ve Roma eser ve bilimsel mirasını tamamen reddetmemiş; uygun ve rasyonel olanlardan istifade etmeyi tercih etmiştir.

Medreselerin fiziki yapisı mevcut mezheplerin varlığ1 ve birbirlerine göre baskınlığından etkilenmiştir.

Medrese günümüzde yükseköğretim bağlamında kıyaslandığı üniversitelerin kendine yakın formalarından çok daha önce ortaya çıkmıştır.

En önemlisi; günümüz
yükseköğretiminin temelini teşkil eden "kolej" sistemi yani kurucu bir vakıf tarafindan finanse ediliyor olma durumu günümüzde de mevcuttur. konuda idari kısım sorumlu ve yetkiliydi, tıpkı günümüz eğitim kurumlarında olduğu gibi. Örneğin, mezuniyet olarak adlandırabileceğimiz icazet, belirli bir müfredat ve program üzerine eğitimi tamamlama değil; eser ve ders alınan eğitmene dayalıydı.

"Eskilerin Bilimi" yabanc1 ve İslamiyet öncesine dayanan, matematik, astronomi, jeodezi, fizik, tıp, gramer, felsefe gibi ilimleri ihtiva ederdi. Medrese, antik dönem bilgeliğinden gelen veya laik olarak nitelendirebileceğimiz bilgiye yönelik bilimsel ögretileri de bünyesinde barındırıyordu. Bu da demek oluyordu ki medreseler veya dönem uleması her ne kadar İslamiyet dini kapsamın öğretilmesinde tutucu davranmışlarsa da eskilerin ilimlerinden istifade etmeyi de bilmișlerdir. $\mathrm{Bu}$ onların bilgiye olan yaklaşımını açıklar nitelikte bir uygulama birlikteliğidir.

Medreselerin fiziki yapısı her şeyden önce sivil mimari gibi fiziki etmenler kadar kendi iç dinamiklerinden de etkilenerek şekillenmiştir. Medrese yapıları içinde her mezhebe uygun olacak şekilde ders anlatım alanları yaratmak amaçlı modeller tercih edilmiş; çoğu medrese birden fazla mezhep için eğitim verilebilecek şekilde planlanmıştır. Dört eyvanlı modelin ortaya çıkış noktasında bu bilgiler kayda değerdir.

Medrese, üniversiteden çok daha eski bir kurumdur; en azından ondan çok daha önceleri ilkel modellerini tamamlayarak kurumsal örneklerine kavuşmuştur. Orta Çă̆ söz konusu olduğunda Hıristiyan Batı'daki yüksek öğretim için emsal kurum olarak gösterildiği üniversitelerin bugünkü hallerine en yakın olan ilk formlarının ortaya çıkması, organizasyonlara dönüşüp kurumsallaşması medresenin yerleşik dönemlerinden çok sonradır. 13. Asır Avrupa'sında birer meslek örgütü olan loncalarla birlikte ortaya çıkmış olan üniversiteler adeta rekabet ve baskıya karşı gelmek için kenetlenen organizasyonlardan doğmuş iken medrese düzenli ve sistematik öğretimin içinden yani önce cami içinde halkalardan, cami yanı mescitlerden ve en nihayetinde ayrı bir kurum olacak kadar kalabalıklaşan Müslümanların eğitim ihtiyacını karşılama amaçlı ortaya çıkmıştır.

$\mathrm{Bu}$ yapının Avrupa eğitim tarihi incelendiğinde Fransa'daki ve İngiltere'deki bazı Orta Çağ yükseköğretim finansman şekilleriyle örtüştüğü de görülebilir.

\section{Etik Beyan}

"İslam Coğrafjasında Erken Dönem Medrese Bileşenleri Üzerine” başlıklı çalışmanın yazım sürecinde bilimsel kurallara, etik ve alıntı kurallarına uyulmuş; toplanan veriler üzerinde herhangi bir tahrifat yapılmamış ve bu çalışma herhangi başka bir akademik yayın ortamına değerlendirme için gönderilmemiştir. Bu araştırma doküman incelemesine dayalı olarak yapıldığından etik kurul kararı zorunluluğu bulunmamaktadır.

\section{Kaynakça}

Adas, M. (Ed.) (1993). Islamic \& European expansion: the forging of a global order (Cilt. 79). Philadelphia: Temple University Press.

Afsaruddin, A. (2005). Muslim views on education: Parameters, purview, and possibilities. J. Cath. Leg. Stud, 44, 143.

Alavi, S. M. Z. (1988). Muslim educational thought in the middle ages. New Delhi: Atlantic Publishers \& Distri.

Al-Hassan, A. Y. (2001). The age of translation and the beginning of the scientific renaissance in science and technology in Islam: The Exact and Natural Sciences. (Ed.) Al-Hassan, A.Y., Makbul, A. and Iskandar, A.Z. (s. 87111). Paris, Lebanon: Unesco Publishing.

Anameriç, H. ve Rukancı, F. (2008). "XI. ve XVI. yüzyıllar arasında medrese ve üniversitelerde eğitim”. Tarih Incelemeleri Dergisi. Cilt XXIII, September/Aralık, Say1/No 2.

Al-Azmeh, A. (1986). Arabic thought and Islamic societies. Beckenham: Routledge.

Arjmand, R., Mirsafa, M., \& Talebi, Z. (2018). Islamic educational spaces: Architecture of madrasah and Muslim educational institutions. International Handbooks of Religion and Education, 469-510.

Berkey, J. P. (2014). The transmission of knowledge in Medieval Cairo: A social bistory of Islamic education (Cilt. 183). New Jersey: Princeton University Press.

Cebeci, S. (2004). Din Eğitiminde Medreseden Mektebe, Mektepten Nereye? Sakarya Üniversitesi İlabiyat Fakültesi Dergisi (SAUIFD), 6(10), 197-201.

Fisher, W. B., Boyle, J. A., ve Richard N. F. (Ed.) (1968). The Cambridge history of Iran (Cilt. 5). Cambridge: Cambridge University Press.

Bozkurt, N. (1993). “Darülhadis” Maddesi. İslam Ansiklopedisi (Cilt. 8). İstanbul: TDV. 
Bozkurt, N. (2003). "Medrese” Maddesi. İslam Ansiklopedisi (Cilt. 28). İstanbul: TDV.

Chamberlain, M. (1994). Knowledge and social practice in Medieval Damascus, 1190-1350. Cambridge: Cambridge University Press.

Cosman, M. P. ve Gale Jones, L. (2009). Handbook to life in the Medieval world, (Cilt. 3) New York: Infobase Publishing. Creswell, K.A.C. (1922). The origin of the cruciform plan of Cairene madrasas. l'Institut Français D'archéologie Orientale.

Çelebi, A. (1983). İslam' da eğitim-ögretim taribi. İstanbul: Damla Yayınevi.

Ellwood, G. (Ed.). (2012). Learning and teaching about Islam: essays in understanding. John Catt Educational Ltd.

Ephrat, D. (2000). A learned society in a period of transition: the Sunni ulama of eleventh century Baghdad. Albany: SUNY Press. Ferngren, G. B. (Ed.) (2002). Science and religion: A historical introduction. Baltimore: JHU Press.

Gözütok, Ș. (2012). İslam'ın altın çağında ilim. Nesil Basım Yayın Gıda Ticaret ve Sanayi A. Ş.

Gutas, D. (1998). Greek thought, Arabic culture: the Graeco-Arabic translation movement in Baghdad and early Abbasid society (2nd-4th/5th-10th c.). New York: Routledge.

Günay, D. (1999). Medreseden üniversiteye trajik bir yolculuk. Mimar ve Mühendis, 26, 41-49.

Gül, A. (1997). Osmanlı medreselerinde eğitim-ögretim ve bunlar arasında Dâru'l-hadîslerin yeri (Cilt. 152). Ankara: Türk Tarih Kurumu Basimevi.

Halm, H. (1997) (2001). The Fatimids and their traditions of learning (Cilt. 2). London: IB Tauris \& Co. Ltd.

Kalaç, R. (2020). Bir hadis ihtisas kurumu olarak Nûriyye ve Eşrefiyye Dârülhadisi. Türkìye Din Eğitimi Araștırmaları Dergisi, (9), 67-82.

Kazıc1, Z. (2010). İslâm eğitim taribi. İstanbul: M.Ü. İlahiyat Fakültesi Vakfı Yayınları.

(1995), (2012). Ana hatlaryla İslam eğitim taribi. İstanbul: İlahiyat Fakültesi Vakfı Yayınları.

Kuban, D. (1985). Muslim religious architecture, 2. Development of religious architecture in later periods. In Muslim Religious Architecture, 2. Development of Religious Architecture in Later Periods. Brill.

Küskü, O. (2020). Doğu-Batı Etkileşiminde Endülüs Emevî Devleti’nin İdari Yapısının Gelişim Süreci. Karatay Sosyal Araștirmalar Dergisi, (5), 112-132.

Madelung, W.., Daftary, F.. \& Meri J. W. (Ed.). (2003). Culture and memory in Medieval Islam: essays in honor of Wilferd Madelung. New York: IB Tauris Publishers.

Makdisi, G. (2012). Ortaçağda yülesek ögretim- İslam dünyası ve Hıristiyan Batı, (Çev. H. T. Başoğlu), İstanbul: Klasik Yayınları.

Mortel, R. T. (1997). Madrasas in Mecca during the medieval period: a descriptive study based on literary sources. Bulletin of the School of Oriental and African Studies, University of London, 236-252.

Öz, M. (1993). "Dâ̂”" Maddesi . İslam Ansiklopedisi. (8. Cilt.) İstanbul.

Özkan, M. (2018). Hicrî VI. yüzyılda Islâm dünyasında ilmî durum. Gökçe, F. (Ed.) Uluslararası Ali b. Osman el-Û̧ş̂ Sempozyumu Bildiriler Kitabı içinde (s. 63-74). Bişkek: Türkiye Diyanet Vakfi- Oş Devlet Üniversitesi İlahiyat Fakültesi.

Özkan, Ş. (2007). Medrese tâbirinin ilk defa ortaya çıkıısı, Selçuklular zamanında medreselerin kuruluş sebebleri ve medrese eğitimi. (Yayınlanmamış Doktora Tezi), Selçuk Üniversitesi, Konya.

Rosenwein, B. H. (2014). A short history of the Middle Ages. (Cilt. I-II).

Sarıçam, İ. ve Erşahin. S. (2014). İslâm medeniyeti tarihi. Türkiye Diyanet Vakfı Yayınları.

Tabbaa, Y. (1997). "Islamic architecture: Form, function and meaning". The Journal of the American Oriental Society, (Cilt. 117) 1.

Turan, O. (1947). Selçuk devri vakfiyeleri I: Şemseddin Altun-aba Vakfiyyesi ve Hayatı, TTK Belleten, XI/42s. 202203.

Turner, J. ve Bernard, P. (1993). The 'German model 'and the Graduate School: The University of Michigan and the origin myth of the American University. History of Higher Education Annual, 13,69-98.

Yılmaz, M. (2013). Sadreddin Konevî’nin huzurunda okunan İbnü'l-Esîr'in Câmi’u'l-Usûl adlı eserinin semâ kayıtları. Cukurova Üniversitesi İlahiyat Fakültesi Dergisi (CÜIFD), 13(2), 1-19.

Yılmaz, H. (2017). Zengî ve Eyyûbî̀ Dımaşk'inda ulema ve medrese. İstanbul: Klasik Yayınları.

Yiğit, İ. (2004). "Mevâlî" Maddesi. İslam Ansiklopedisi (Cilt. 29). İstanbul: TDV.

Zengin, F. A. M., \& Kaymaz, K. C. Y. (2016). Osmanlı medreseleri: Eğitim, yönetim ve finans. İstanbul: Mahya Yayinc1lik.

\section{EXTENDED ABSTRACT}

Madrasas emerged with the first years of Islam and they were derived from mosques as units where Islamic education took place. Islamic science and academic studies of the period were also carried out at medium and higher levels in these institutions. While madrasas, which existed long before the rise of universities, belongs to the Islamic world and born entirely within Islamic norms; the Medieval university prototype is an institution specific to the West, especially Europe. The proliferation of madrasas as a science center, their free education and their spread to different Muslim geographies occurred especially during the Seljuk period. In this case, the madrasa was in the center of the religious dimension and had a religious education-oriented character, as the church and cathedral schools were also born within the 
Church in the West las well as the monasteries established by Christian monks who mostly led a hermit's life. And it is almost possible to claim that madrasa has emerged long before the universities, the institution with which it has always been compared in the context of higher education today. Besides, in madrasas 'different parts and sections, academical studies called Social Sciences were discussed and studied in halqahs, masjids, maristanas and bimaristanes, medical centers, hospitals or libraries stemming from these. Paralleled to these, ribats, zawiyahs or khanqahs can be counted among centers where different kinds of educational practices took place. With the birth of madrasas, the study of foreign sciences gradually decreased and new institutions bearing the word "Dâr" began to emerge. These were the institutions which existed before madrasas; ijtihat and Qur'anic education were realized here as well. Madrasas were derived from the combination of mosque and other islamic institutions like khanqahs, ribats, etc. because all signified an institution with education and accommodation facilities in the same environment. Apart from their capacity, these institutions were the heart of sociopolitical controversies as a result of the then present status quo of Islamic civilizations. Topics like fate, free-will, punishment, etc. had been discussed and been the central issues on which there had been many controversies in Islamic theology and the related halqahs. These theological controversies led to some intellectual movements in Arabic society causing people with the common ideas get together. They preferred to get together regularly with the aim of discussing and teaching the related issues they all advocate. Each Islamic view and Islamic school had the tendency to provide education according to its own approach so there were also rivalry and contradiction among present Islamic schools and religious cults. For instance, Shi' ite Fatimid and Sunni Seljuks were the two-competing civilization in terms of both political and educational areas with respect to their madrasas and higher educational aspects. Apart from Islamic schools, centers meant a lot for Islamic facilities. The main intellectual centers at the time can be counted as Eastern Islamic centers of Abbasids while the second one is Andalucia. For this reason, compared to the university as an example and as a higher education center, madrasa was a medium for religious education and a tool for spreading the religious education pillars of Islam. The factors affecting madrasas can be counted as state administration, dominant sects, their members' views and practices in education, foundations and administrative practices. Madrasa had also some individual components like lecturers, students, administrators, etc. even the physical capacity and layout were determinants for its educational characteristics as the construction of a typical madrasa style meant a lot for the functioning of the institution. Because they were mostly open to various Islamic schools instead of one. There were two classes of people responsible for education and administrators in the madrasa organization. As in today's education systems, madrasa contained some administrative practices as well as elements of education within its corporate identity. From the employment of professors to the works to be taught, the administrative part was responsible and authorized, just like today's educational institutions. As for managerial details, it is possible to infer that the "college" system which is the basis of today's higher education institutions was prevalent in educational milieus at the time. When the European education history is examined, it can be seen that these institutions 'properties coincide with some Medieval higher education funding types in France and England. To some up, the aim of the study is to provide an insight on the academical and administrative aspects prevalent in these kinds of institutions. All these have been among what makes a typical madrasa an educational institution in general. More effort on behalf of the researchers in the field is necessary to increase in the number of studies that examine the concept of madrasa of each civilization separately and in terms of its individual components according to contemporary dynamics. 